\title{
Rethinking University Assessment
}

\author{
Peter Williams \\ University of Hull, Faculty of Education, UK
}

\begin{abstract}
Developments in globalisation and new technologies are making significant impacts in higher education. Universities in a global market are increasingly concerned to reorient their degree programmes to meet the vocational needs of the Knowledge Economy. A growing adoption of technology enhanced learning, through blended and networked learning, has the potential to transform higher education practice - but assessment methods have been slow to change. This paper argues the case for universities to align assessment methods to meet the needs of 21st Century knowledge workers. It identifies skills and dispositions associated with graduate occupations in the Knowledge Economy, informing a new conceptual model for assessment. Radical recommendations are made to faculty staff and university policymakers: instead of centring assessment on the personal, academic achievements of individuals at the end of a degree course, the focus should instead be on the quality of the collective, applied achievements of students operating in project teams.
\end{abstract}

\section{Introduction}

Diana Laurillard's 1993 book, the much-cited Rethinking University Teaching [22], proposed a theoretical underpinning for the employment of learning technology that also embraced wider pedagogical perspectives; the book predated the World Wide Web and the substantial developments that followed. Two decades later, the educational use of information and communication technology (ICT) for teaching in universities has grown beyond the stage of 'letting a thousand flowers bloom' [11] to a more evidence-based deployment of established technologies in what Taylor calls a fifth generation Intelligent Flexible Learning Model [41] exploiting the unique affordances of the Web. Innovative teaching tools have enhanced course delivery and tools for online interaction have engaged students beyond the immediate classroom. However, comparable changes have not been apparent in the methods of assessment used in higher education.

This paper examines those aspects of undergraduate students' performance that are addressed by formal assessment methods and relates them to the skills, knowledge, understanding and dispositions needed for successful performance in the graduate occupations that students report are a major motivation for undertaking university study [7]. Important differences are identified between the graduate professions of the 20th Century and the occupations of the 21st in what is widely known as the Knowledge Economy [31]. The latter are more transient and fluid, requiring frequent updating of knowledge and skills. The greater collaboration made possible by ICT has created new requirements for team working in a business environment described by Manuel Castells as 'timeless time and the space of flows' [8].

It is the contention of this paper that current assessment practices in universities reflect the ways of working of the old graduate professions and so reward performance in areas that are of diminishing relevance to emerging needs. It has therefore become necessary to rethink university assessment in terms of its epistemological purpose and to harness new technologies in the monitoring and analysis of the complex interactions and behaviours of students operating in collaborative teams to address realistic problems in simulated and work-based environments.

The paper concludes with a significant recommendation for university policymakers: that instead of centring assessment on the personal, academic achievements of individuals at the end of a degree course, the focus should instead be on the quality of the collective, applied achievements of students operating in project teams.

\section{21st Century needs}

Over thirty years ago, the growth of a new 'primary information sector' was predicted by Porat and Rubin [30], who saw the key workers in this sector typified by scientists and writers, creating and disseminating new ideas. These roles require particular skills in the location and processing of information in digital formats, solving problems, and creating and disseminating new knowledge across networks. Through the medium of Information and Communication Technology (ICT), the epistemological nature of this generated and shared 
knowledge is becoming more differentiated. Williams [44] comments on the diversification from the formal, propositional knowledge of experts traditionally print-based - to the informal, procedural knowledge of practitioners, enabled by massive growth in the capacity and versatility of ICT networks, and notes a growing trend from just-incase to just-in-time learning. The skills of information workers in the Knowledge Economy [14] go beyond the generic habits of critical thinking and reflection identified by Schön [38] to include those more specific to working with ICT.

The Assessment \& Teaching of 21st Century Skills (ATC21S) [4], an international organisation headquartered at the University of Melbourne, identifies collaborative problem solving and learning in digital networks as key skills for workers in the Knowledge Economy. The organisation has published a number of White Papers including Assessment and Teaching of 21st Century Skills [17], with chapters cited elsewhere in this paper.

A more complex taxonomy of skills is provided by Reinhardt et al. [35], who examined empirical data and recent literature in this area to identify ten information worker roles: Controller, Helper, Learner, Linker, Networker, Organizer, Retriever, Sharer, Solver, Tracker. These roles involve different combinations of 49 'expected knowledge actions', which are here categorized into three broad groups of Collecting, Processing and Transmitting knowledge, as presented in Figure 1. Personal qualities and dispositions feature in the group of expected knowledge actions labelled as Transmitting, as these include the co-creation and sharing of knowledge within teams.

The intensely collaborative nature of these new ways of working demands certain personal qualities and dispositions [15] that have not traditionally been the focus of formal assessment by universities. An international survey conducted by the OECD [28: 106] located the following competencies as having broad agreement between analysts and countries:

'Inter-personal skills:

- Team work and the ability to collaborate in pursuit of a common objective.

- Leadership capabilities.

Intra-personal skills:

- Motivation and attitude.

- The ability to learn.

- Problem-solving skills.

- Effective communication with colleagues and clients.

- Analytical skills'.

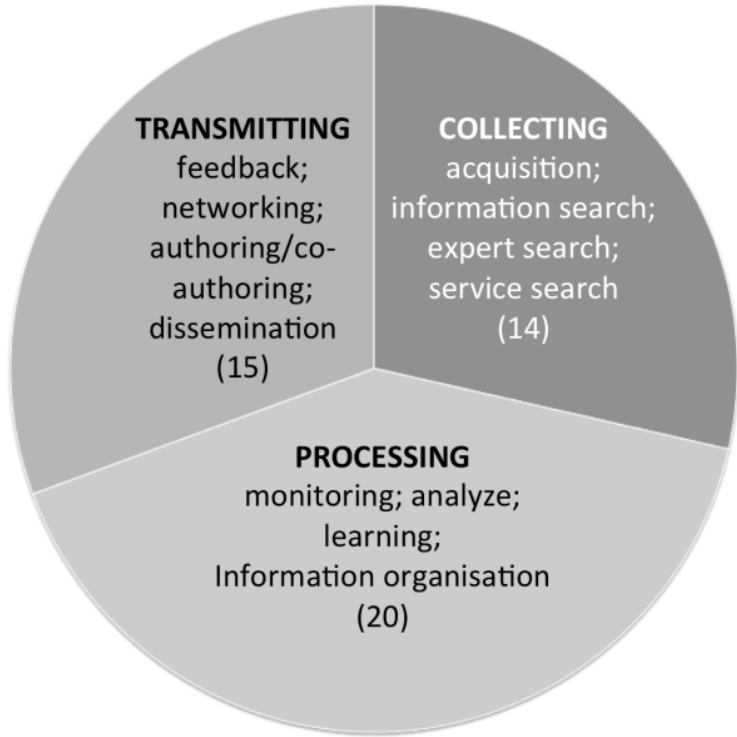

\section{Figure 1: Typology of knowledge worker roles and expected knowledge actions (derived from data by Reinhardt et al. [35])}

Inter-personal and intra-personal qualities are also evident in an analysis of the views of European teachers and expert panels on the skills required to address new labour market trends and demands [33]. The first is personal skills, including initiative, responsibility and creativity. The second is social skills, including team working, empathy and coconstructing. The third is learning skills, including managing, organizing and metacognition.

In addition to the premium on information processing and flexible learning are roles and actions relating to patterns of working in which human engagement and communication are central. Traditionally, such soft skills have not been a part of university curricula, but several studies recommend they should be given greater emphasis: for example, with Information Systems students in the USA [26], in business education in Europe [2] and in a national higher education policy in Malaysia in which soft skills are a statutory component of the curriculum [36].

The resonance between these taxonomies is reflected in an extensive literature review conducted in 2010 [43] that indicates widespread agreement on the key skills and dispositions entailed in the Knowledge Economy. Over 30 working papers, ICT competency standards and reports from international studies were examined and compared. Collaboration, communication and social and/cultural competencies were common to all the literature reviewed, with mention of creativity, critical thinking and problem solving appearing in many. 


\section{New assessment needs}

The move to modularisation and semesterisation in many universities has led to an increase in the frequency of high-stakes summative assessments conducted at the ends of semesters - with a corresponding reduction in the opportunities for formative assessment and feedback to students [40]. Gibbs [16] notes a changed focus from integrative and processual to discrete and content-bound assessment. The associated shift towards what Knight [20] calls warranting - summative assessment leading to the generation of (seemingly objective) grades - has a narrowing effect on students' perceptions of what is important and deserving of attention. Biggs [6] calls this the backwash effect, whereby the content of what is being assessed influences strategic learners to focus only on what will gain them higher grades. Such behaviour runs counter to attempts to broaden the curriculum through soft skills and orient it towards 21st Century needs; many traditional assessment practices and related assumptions therefore seem out of step and in need of radical change.

An analysis of recent literature on assessment in higher education indicates a number of issues that are here grouped into three categories related to the needs discussed earlier.

The first category is what might be called the granularity of assessment: the frequency and scheduling of assessment points throughout the learning process. As discussed earlier, a preponderance of summative assessment can have the effect of distorting the curriculum and learners' behaviour. Related to this is a perception of warranting assessment as something that is 'done to students' by their tutors, rather than as a process shared through dialogue in 'constructive alignment' with learning and teaching [5] This latter approach of dialogic assessment [32] is closely linked with Assessment for Learning, taking a constructivist epistemological stance that there is no supposed external entity that can be subjected to objective, valid and reliable measurement [37]. As the purpose of this approach is not to warrant but to engage, peer assessment and reflective self assessment are encouraged.

The second category is concerned with the epistemology of what is being assessed. Much traditional assessment is institution-oriented and located. It grades students principally on their recall and understanding of propositional knowledge knowledge that is formal, organised and relatively straightforward to assess. A contrasting approach is taken by the advocates of alternative assessment. A framework model for authentic assessment, developed by Gulikers et al. [18] from the perceptions of students and teachers of a vocational course in nursing, identified five sets of criteria by which authentic assessment activities must closely resemble the practice environment. These comprised the assessed tasks, the physical and social contexts and how authentic were the outcomes and assessment criteria employed. The focus is upon procedural knowledge and its application altogether less defined and more difficult to grade than formal knowledge [25].

The third category of issues overlap to some extent with the previous, and concern the subject of assessment and how judgements are arrived at. Universities commonly employ norm-referencing, whereby a student's individual performance in the completion of given tasks is compared to expected levels in relation to the group from which the student is drawn. By contrast, the sort of practice-based judgements made in authentic assessment settings are criterion-referenced, observing whether or not discrete tasks have been successfully completed. A further difference between the settings for traditional and authentic assessment is typically in the extent to which tasks undertaken by individuals are interdependent on others, and there is a greater likelihood of collaborative working and team communication to be found in the latter.

Darling-Hammond [13] compares the policy frameworks for assessment systems in Australia, Finland, Singapore, and the UK, noting moves in the direction of project- and inquiry-based learning and the use of ICT in solving authentic problems. There is considerable resonance between these developments and the notion of cognitive apprenticeship [10], in which ill-defined problems situated in authentic environments are addressed through peer interaction. Several studies ([32]; [21]; [40]), have explored cognitive apprenticeship in relation to digital networks and authentic learning environments.

\section{Epistemology and assessment}

The assumptions underlying sets of assessment practices may be difficult to explicate, and there is evidence that they reflect epistemological and ontological beliefs. People differ in their epistemological world view - the set of beliefs they hold on the nature of knowledge. They differ also in their ontological beliefs concerning the nature of reality. Research by Olafson et al. [29] into the pedagogical beliefs of school teachers undertaking postgraduate study found consistent relationships between the views teachers held about knowledge and reality (whether it was subjective/internal or objective/external) and their preferred pedagogical approaches. Realists, who regard teaching as the transmission of objective knowledge developed by experts to passive students, are more likely to employ norm-referenced testing to monitor success. Relativists regard knowledge as subjective, 
individually constructed and unique. Their pedagogical practices include projects, studentdirected learning and critical thinking, and assessments are typically criterion-based around individual student's needs. Contextualists see their students very differently, as constructing understanding through shared learning activities grounded in authentic contexts. Such teachers encourage peer learning and authentic assessment.

Epistemological stances are clearly evident in traditional university assessment, where a particular view of knowledge influences curriculum content and how it should be assessed. The formal, propositional knowledge of experts referred to earlier, and sometimes referred to as Mode 1 knowledge [27] is dominant in higher education and traditionally has shaped assessment to be similarly formal, abstract and set at a distance from the contexts for its application in the world. By contrast, Mode 2 knowledge [27], the informal, procedural knowledge of practitioners, is very much the raw material as well as the product of the Knowledge Economy, and as Williams [44] argues presents a significant challenge to traditional practice. In the view of Usher [42: 146]:

'One consequence of this is that anything anywhere is now potentially researchable by a wide variety of knowledge producers in a wide variety of sites. These knowledge producers are no longer solely accountable to the gatekeepers and epistemological policing of disciplinary communities. Indeed, they are much more likely to be responsible to communities of practice within their workplace. Moreover, they no longer have to be exclusively located in the academy'.

\section{Connectivism and Learning Analytics}

There are parallels between the pedagogical stances of Realists, Relativists and Contextualists and the dominant learning theories of, respectively, behaviourism, cognitivism and constructivism, which are also underpinned by epistemological beliefs. In 'Connectivism: A Learning Theory for the Digital Age' [39], Siemens argues the case for an alternative theory that reflects the new priorities of the Knowledge Economy. In common with constructivists, connectivists see knowledge as socially constructed, but regard learning as the connection of nodes on a network. The ability to make these connections is a core skill, and maintaining interactions across the network to facilitate continual learning is necessary in order to keep knowledge current. Important decisions involved in this sensemaking process include choosing what to learn through an integration of informal with formal knowledge.

Learning Analytics is 'the measurement, collection, analysis and reporting of data about learners and their contexts, for purposes of understanding and optimising learning and the environments in which it occurs' [1, unpaged]. Most applications of this method have used the data generated by students' online activities to target interventions in the form of study advice and support, especially for those identified to be 'at risk' - an example being Course Signals at Purdue University [3]. In their examination of the conceptual underpinnings of Learning Analytics, Knight et al. [21] see assessment, pedagogy and epistemology as fundamentally interlinked. They suggest that the practice of high stakes assessment runs counter to the benefits of Assessment for Learning and authentically situated learning. While Learning Analytics has in the past been used for purposes epistemically similar to those of traditional assessment, they propose pragmatic, sociocultural applications in which it could be used to support formative assessment approaches.

\section{A new assessment model}

In Figure 2 the three categories of issues introduced in Section 2 have been represented as dimensions, each extending from 0 to 1 . The Granularity dimension ranges from $\mathrm{G}_{0}$ - summative and tutor-assessed to $\mathrm{G}_{1}$ - formative, dialogic and peer-assessed. The Epistemology dimension ranges from $\mathrm{E}_{0}-$ institution-based and focused on propositional (Mode 1) knowledge, to $E_{1}-$ in an authentic setting and focused on procedural (Mode 2) knowledge. Finally, the Subject dimension ranges from $S_{0}$ - the norm-referenced grading of individuals to $\mathrm{S}_{1}$ - the criterion-referenced competencies of collaborating teams.

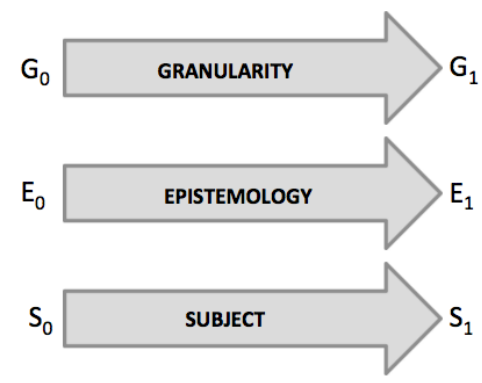

\section{Figure 2: Dimensions of assessment, ranging from 0 to 1}

If the three dimensions are arranged orthogonally as $\mathrm{x}, \mathrm{y}$ and $\mathrm{z}$ axes it becomes possible to represent a variety of assessment practices in 3-dimensional view.

Figure 3 illustrates a composite cube constructed from eight component cubes. The component cube at coordinates $\mathrm{G}_{0}, \mathrm{E}_{0}, \mathrm{~S}_{0}$ is located in what might be called the 'traditional corner': typified by the 
summative, and norm-referenced assessment of propositional knowledge involved in tasks performed by individual students. The component cube at coordinates $\mathrm{G}_{1}, \mathrm{E}_{1}, \mathrm{~S}_{1}$ is located in what might be called the 'alternative corner': typified by the formative, dialogic and criterion-referenced assessment of procedural knowledge involved in collaborative team working. Thus, the model provides a visual representation of the many ways in which alternative methods of assessment can differ from traditional practices.

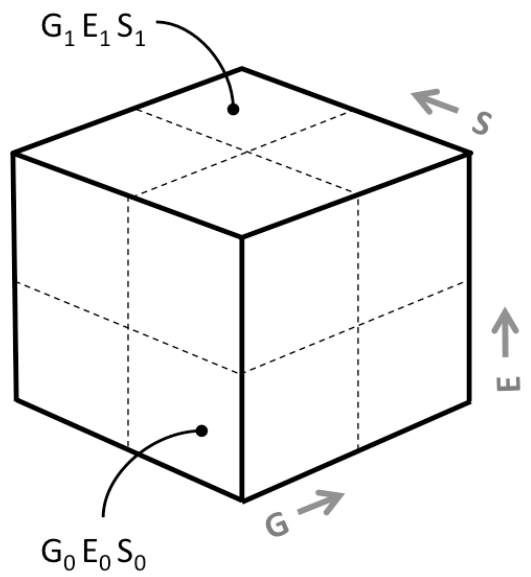

\section{Figure 3: orthogonal model of assessment, comprising dimensions of Granularity, Epistemology and Subject}

\section{Using the model}

The conceptual model presented in Figure 3 can be used to locate assessment practices that best relate to the $21^{\text {st }}$ Century skills and dispositions identified earlier; Table 1 maps these to assessment foci. In the two main columns of Table 1 the sets of key skills identified by ATC21S [4] have been associated with the three broad groups of expected knowledge actions derived from Reinhardt et al. [35] (Figure 1). Foci by which these keys skills and actions might be assessed are in the three main rows of the table, and these have been related to the dimensions of Granularity, Epistemology and Subject.

It can be seen from the table that there is a close affinity between the skills of knowledge working and the three dimensions as assessment foci. Collaborative problem solving, mainly involving the knowledge actions of processing and transmitting, may be assessed more appropriately through a dialogic process of Assessment for Learning and peer involvement $\left(\mathrm{G}_{1}\right)$ than by infrequent summative assessment $\left(\mathrm{G}_{0}\right)$. What is being assessed particularly involves procedural knowledge embedded in the problem context $\left(\mathrm{E}_{1}\right)$ more than propositional knowledge that may have partial applicability $\left(\mathrm{E}_{0}\right)$; and the focus of assessment in on whether the team as a whole is operating effectively $\left(S_{1}\right)$ rather than on the performance of individual members $\left(\mathrm{S}_{0}\right)$.

\section{Table 1: mapping of $21^{\text {st }}$ Century skills to the three dimensions of assessment}

\begin{tabular}{|c|c|c|c|}
\hline \multicolumn{2}{|c|}{$\begin{array}{l}21^{\text {st }} \\
\text { Century } \\
\text { skills } \\
\text { (ATC21S) }\end{array}$} & $\begin{array}{l}\text { Collaborative } \\
\text { problem solving } \\
\text { (Processing and } \\
\text { Transmitting) }\end{array}$ & $\begin{array}{c}\text { Learning in digital } \\
\text { networks } \\
\text { (Collecting and } \\
\text { Processing) }\end{array}$ \\
\hline \multirow{3}{*}{ 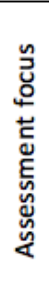 } & $\mathrm{G}_{1}$ & $\begin{array}{c}\text { dialogic process; } \\
\text { peer support }\end{array}$ & $\begin{array}{l}\text { formative feedback; } \\
\text { peer communication }\end{array}$ \\
\hline & $\mathrm{E}_{1}$ & $\begin{array}{c}\text { procedural } \\
\text { knowledge } \\
\text { of 'what works' }\end{array}$ & $\begin{array}{l}\text { authentic settings; } \\
\text { typical tasks, } \\
\text { contexts \& outcomes }\end{array}$ \\
\hline & $\mathrm{S}_{1}$ & $\begin{array}{c}\text { collaborative team } \\
\text { working }\end{array}$ & $\begin{array}{l}\text { criterion-referenced } \\
\text { competencies }\end{array}$ \\
\hline
\end{tabular}

Similarly, learning in digital networks, mainly involving the knowledge actions of collecting and processing, may be assessed more appropriately through frequent communication and formative feedback from fellow learners $\left(G_{1}\right)$ than by assessment scheduled only at end points in the learning process $\left(\mathrm{G}_{0}\right)$; the nature of such learning in authentic settings and involving authentic outcomes is likely to be experiential and procedural $\left(E_{1}\right)$ rather more than propositional $\left(\mathrm{E}_{0}\right)$; and criterionreferenced competencies $\left(S_{1}\right)$ seem more appropriate as ways of assessing the personal interactions that contribute to collective learning than the normreferenced grading of individual learners.

\section{Recommendations for universities}

The purpose of this paper is to make recommendations directed to all faculty staff engaged in planning university curricula and assessing students' performance, and to institutional policymakers.

The first recommendation concerns the new context within which universities must now operate. Laurillard [23: 134] poses two 'difficult questions' concerning their continuing role and purpose. The first is 'how should the curriculum balance expert knowledge and practitioner knowledge?' This question relates to the Epistemology dimension in Figure 2 and to the rapid growth of Mode 2 knowledge as the definitive product of the Knowledge Economy. As Williams [44] notes, the issue of what is to be regarded as 'valid knowledge' becomes of crucial importance. Laurillard's second and related question is 'to what extent is a degree course a long-term grounding for an individual?' The concerns voiced by Usher [42: 146] that knowledge is increasingly being generated outwith the academy has important implications. As this knowledge 
typically has a shorter half-life [24] than Mode 1 knowledge, it follows that a greater premium should be placed on the skills of Collecting, Processing and Transmitting that Reinhardt et al. [35] say characterise knowledge working. A major change is needed in the selection of curriculum content and in how best to prepare students for this more uncertain future.

The second recommendation of this paper follows directly from the first: changes in curriculum content and orientation should be accompanied by changes in methods of assessment. Norm-referenced and summative assessments of the performance of students working individually on academic exercises may have high reliability, but questions must be raised as to their predictive validity - as indicators of future success in what will be very different environments. The most striking way in which these environments differ is in the degree of collaborative working involved and the deployment of soft skills that underpin success.

The evidence examined suggests that universities should concentrate on increasing the permeability of their institutional boundaries to encourage the creation of rich settings for situated, authentic learning. Hence, the key indicators of performance and prestige for universities would become the quality of the cognitive apprenticeship and dialogic support they could provide for effective peer working. So instead of assessment centring on the personal, academic achievements of individuals at the end of a degree course, the focus would instead be on the quality of the collective, applied achievements of students operating in project teams. To employ Knight's term, the 'warranting' of graduates would be judged by their effective engagement in successful, collective enterprises. The model presented in Sections $5 \& 6$ provides an executive summary to underpin these recommendations, and the proposed new assessment priorities would evaluate the $21^{\text {st }}$ Century skills by means of the three assessment foci, as presented in Table 1.

The problems of moving from individual assessment under controlled conditions to group assessment in external and more complex environments are considerable and require new techniques. The fact that many collaborative engagements leave a digital data trail provides the potential for assessment through the analysis of communications and interaction patterns. The approaches and epistemological stance of alternative assessment may now become realisable in what Williams calls 'a new alternative to alternative assessment' [45]. Technology based assessment of this form is examined by Csapó et al. in an ATC21S White Paper [12], where the analysis of learners' interactions in complex environments can be captured for automated scoring, and feedback and reporting. More specifically, the rapidly developing field of Learning Analytics shows considerable promise, and Knight et al. [21] explore its possible deployment to support formative and dialogic assessment. Redecker [34] also sees opportunities for Learning Analytics, recommending that it be embedded in immersive digital environments, games and simulations to monitor learners' engagement in authentic contexts in which 21 st Century skills can be practised and displayed. Through the analysis of large and complex datasets recording group interactions, the detailed assessment of students' team working as well as their individual performance will become possible. Redecker's 30-year timeline for assessment (ibid.) outlines a transition from the early use of ICT for efficient testing, through Learning Analytics and behavioural tracking, towards continuous, integrated assessment and personalised feedback.

Universities are advised to give urgent consideration to these recommendations. A radical rethinking of assessment practices is needed in order to more appropriately meet the needs and expectations of current students. In terms of the three dimensional model of assessment developed in this paper: more finely-grained monitoring must be developed to provide students with greater formative feedback; more authentic settings for learning should meet students' expectations of vocational relevance; and a far broader range of students' achievements should be addressed, including collaborative working and the application of soft skills.

\section{Conclusion}

This paper has examined the needs of graduate occupations in the Knowledge Economy, identifying the qualities and dispositions associated with successful working. Such $21^{\text {st }}$ Century roles require particular skills in the location and processing of information in digital formats, solving problems, and creating and disseminating new knowledge across networks - and for these roles the soft skills of engagement and collaborative team working are paramount. However, evidence has been advanced that such personal and social skills may not be well addressed in many university curricula.

While some universities have been innovative in their adoption of technology enhanced learning in course delivery, methods of assessment have been slow to change. Traditional assessment appears to be predicated upon epistemological assumptions of the objectivity and externality of knowledge; in the model of assessment proposed above this locates at the $\mathrm{E}_{0}$ end of that dimension. Traditional assessment is also typically coarse grained and summative $\left(\mathrm{G}_{0}\right)$ and more likely to focus on the norm referenced performance of individual students $\left(\mathrm{S}_{0}\right)$. 
It has been argued that a strong affinity exists between Knowledge Economy skills and assessment in the forms defined in the model as $\mathrm{G}_{1} \mathrm{E}_{1} \mathrm{~S}_{1}$. Moreover, the affordance of Learning Analytics for the continuous, integrated assessment of collaborative working - coupled with the ongoing provision of personalised feedback - has the potential to transform the nature of higher education. From this analysis the paper makes recommendations for universities to embrace radically different assessment priorities and practices. Instead of centring assessment on the personal, academic achievements of individuals at the end of a degree course, the focus should instead be on the quality of the collective, applied achievements of students operating in project teams.

\section{References}

[1] 1st International Conference on Learning Analytics and Knowledge, Banff, Alberta, February 27-March 1, 2011. https://tekri.athabascau.ca/analytics/

[2] Andrews, J. and H. Higson. 2008. Graduate employability, 'soft skills' versus 'hard' business knowledge: a European study, Higher Education in Europe 33, no. 4: 411-422.

[3] Arnold, K. and M. Pistilli. 2012. Course Signals at Purdue: Using learning analytics to increase student success. Proceedings of the 2nd International Conference on Learning Analytics \& Knowledge. New York: ACM.

[4] Assessment \& Teaching of 21st Century Skills project (ATC21S). http://atc21s.org/

[5] Biggs, J. 1996. Enhancing teaching through constructive alignment. Higher Education 32, no. 3: 347364.

[6] Biggs, J. 1999. Teaching for Quality Learning at University. Buckingham, UK: SRHE and Open University Press.

[7] Bui, K. 2002. First-generation college students at a four-year university: background characteristics, reasons for pursuing higher education, and first-year experiences. College Student Journal 36, no. 1: 3-11.

[8] Castells, M. 1996. The Rise of the Network Society (Vol.1). Oxford: Blackwell.

[9] Cawthon, S., A. Harris and R. Jones. 2010. Cognitive Apprenticeship in an Online Research Lab for Graduate Students in Psychology. Web-Based Learning and Teaching Technologies 5, no. 1: 1-15.

[10] Collins, A., J.S. Brown and S. Newman S. 1989. Cognitive apprenticeship: teaching the craft of reading, writing and mathematics. In L. Resnick (ed.), Knowing, Learning and Instruction; Essays in Honor of Robert Gluser (pp. 453-494). Hillsdale, USA: Lawrence Erlbaum.
[11] Collis, B. 1997. Implementing ICT in the faculty: Letting a 1,000 flowers bloom or managing change? In $D e$ digital leeromgeving [The digital learning environment], M. Miranda, J. Riemersma and W. Even, eds., 121-136. Groeningen, NL: Wolters-Noordhoff.

[12] Csapó, B., J. Ainley, R. Bennett, T. Latour and N. Law. 2012. Technological Issues for Computer-Based Assessment. In Assessment and Teaching of 21st Century Skills, P. Griffin, B. McGaw and E. Care, eds., 143-230. Netherlands: Springer.

[13] Darling-Hammond, L. 2012. Policy Frameworks for New Assessments. In Assessment and Teaching of 21st Century Skills, P. Griffin, B. McGaw and E. Care, eds., 301-339. Netherlands: Springer.

[14] Drucker, P. 1969. The Age of Discontinuity: Guidelines to Our Changing Society. New York: Harper \& Row.

[15] Ducatel, K. 1998. Learning and skills in the knowledge economy. DRUID Working Paper No. 98-2, Danish Research Institute for Industrial Dynamics, Aalborg University.

[16] Gibbs, G. 2006. Why assessment is changing. In Innovative Assessment in Higher Education, C. Bryan and K. Clegg, eds., 11-22. Abingdon, UK: Routledge.

[17] Griffin, P., B. McGaw and E. Care, eds. Assessment and Teaching of 21st Century Skills. Netherlands: Springer.

[18] Gulikers, J., T. Bastiaens and P. Kirschner. 2004. A five-dimensional framework for authentic assessment. Educational Technology Research and Development 52, no. 3: 67-86.

[19] Järvelä, S. 1995. The cognitive apprenticeship model in a technologically rich learning environment: Interpreting the learning interaction. Learning and Instruction 5, no. 3: 237-259.

[20] Knight, P. 2007. Grading, classifying and future learning. In Rethinking Assessment in Higher Education, D. Boud and N. Falchikov, eds., 72-86. Abingdon, UK: Routledge.

[21] Knight, S, S. Buckingham Shum and K. Littleton. 2013. Tracking epistemic beliefs and sensemaking in collaborative information retrieval. In Collaborative Information Seeking Workshop 2013: Consolidating the Past, Creating the Future, 24 Feb 2013, San Antonio, USA.

[22] Laurillard, D. 1993. Rethinking University Teaching: a framework for the effective use of educational technology. London: Routledge.

[23] Laurillard, D. 2002. Rethinking Teaching for the Knowledge Society. EDUCAUSE Review 37, no. 1: 16-25. https://net.educause.edu/ir/library/pdf/ffpiu017.pdf 
[24] Machlup, F. 1962. The production and distribution of knowledge in the United States. Princeton: Princeton University Press.

[25] Maclellan, E. 2004. How convincing is alternative assessment for use in higher education? Assessment \& Evaluation in Higher Education 29, no. 3: 311-321.

[26] Noll, C. and M. Wilkins. 2002. Critical skills of IS professionals: a model for curriculum development. Journal of Information Technology Education: Research 1, no. 1: 143-154.

[27] Nowotny, H., P. Scott, M. Gibbons. 2001. ReThinking Science: Knowledge and the Public in an Age of Uncertainty. Oxford: Polity Press.

[28] OECD. 2001. Competencies for the Knowledge Economy. In Education Policy Analysis 2001, 99-118. Organisation for Economic Co-operation and Development. OECD Publishing.

[29] Olafson, L., G. Schraw and M. Vander Veldt (2010) Consistency and development of teachers' epistemological and ontological world views. Learning Environments Research 13, no. 3: 243-266.

[30] Porat, M., and M. Rubin. 1977. The Information Economy (9 volumes). Office of Telecommunications Special Publication 77-12. Washington DC, US: Department of Commerce.

[31] Powell, W. and K. Snellman. 2004. The knowledge economy. Annual Review of Sociology 30: 199-220.

[32] Price, M., J. Carroll, B. O'Donovan and C. Rust. 2008. Assessment Standards: A Manifesto for Change. Brookes eJournal of Learning and Teaching 2, no. 3 (unpaged).

[33] Redecker, C., M. Leis, M. Leendertse, Y. Punie, G. Gijsbers, P. Kirchner, S. Stoyanov and B. Hoogveld. 2011. The Future of Learning: Preparing for Change. Joint Research Centre: Institute for Prospective Technological Studies. Luxembourg: European Commission.

[34] Redecker, C. 2013. The Use of ICT for the Assessment of Key Competences, Joint Research Centre: Institute for Prospective Technological Studies. Luxembourg: European Commission.

[35] Reinhardt, W., B. Schmidt, P. Sloep, and H. Drachsler. 2011. Knowledge worker roles and actions results of two empirical studies. Knowledge and Process Management 18, no. 3: 150-174.

[36] Salih, M. 2008. Realizing sustainable development of higher education in Malaysia through 'soft skills'. Indian Journal of Science and Technology 1, no. 5: 1-9.

[37] Sambell, K., L. McDowell and C. Montgomery. 2013. Assessment for Learning in Higher Education. Abingdon, UK: Routledge.

[38] Schön, D. 1983. The Reflective Practitioner: How Professionals Think in Action. New York: Basic Books.
[39] Siemens, G. 2005. Connectivism: a learning theory for the digital age, International Journal of Instructional Technology \& Distance Learning 2, no. 1 (unpaged).

[40] Taras, M. 2002. Using assessment for learning and learning from assessment. Assessment \& Evaluation in Higher Education 27, no. 6: 501-510.

[41] Taylor, J. 2001. Fifth Generation Distance Education. e-Journal of Instructional Science and Technology, 4, no. 1: 1-14. http://eprints.usq.edu.au/archive/00000136/01/Taylor.pdf

[42] Usher, R. 2010. A diversity of doctorates: fitness for the knowledge economy? Higher Education Research \& Development 21, no. 2: 143-153.

[43] Voogt, J. and N. Roblin. 2010. 21st Century skills. Discussion paper. University of Twente, Netherlands. http://opite.pbworks.com/w/file/fetch/61995295/White\%20 Paper\%2021stCS_Final_ENG_def2.pdf

[44] Williams, P. 2007. Valid knowledge: the economy and the academy. Higher Education 54, no. 4: 511-523.

[45] Williams, P. 2014. Squaring the Circle: a new alternative to alternative-assessment. Teaching in Higher Education.

http://www.tandfonline.com/doi/full/10.1080/13562517.20 14.882894\#.UvuKI3kXrFk 